\title{
Estrogenic activity and cytotoxicity of six anticancer drugs detected in water systems
}

\author{
Alfredo Parrella, Margherita Lavorgna, Emma Criscuolo, Chiara Russo, Marina Isidori* \\ Dipartimento di Scienze e Tecnologie Ambientali, Biologiche e Farmaceutiche, Seconda Università di Napoli, Via Vivaldi 43, I-81100 Caserta, Italy
}

\section{H I G H L I G H T S}

- Estrogenic activity and cytotoxicity of six cytostatics were assessed.

- Imatinib, cisplatin and 5-fluorouracil had the highest estrogenic effect.

- This study contributes to cytostatic environmental risk evaluation.

\section{A R T I C L E I N F O}

\section{Article history:}

Received 22 January 2014

Received in revised form 12 March 2014

Accepted 12 March 2014

Available online 12 April 2014

Editor: D. Barcelo

\section{Keywords:}

Cytostatics

Anticancer drugs

Endocrine activity

Cytotoxicity

Environmental pollution

\begin{abstract}
A B S T R A C T
The aim of the present study was to investigate the in vitro estrogenic and the cytotoxic activity of six cytostatics (5-fluorouracil, capecitabine, cisplatin, doxorubicin, etoposide, and imatinib) belonging to the five classes of Anatomical Therapeutic Classification (ATC) detected in wastewater systems. The estrogenic activity was assessed by YES-assay on Saccharomyces cerevisiae-RMY326 and E-screen on MCF-7 cells. The cytotoxic activity was assessed by MTT Cell Proliferation Assay on the MCF-7 and the MDA-MB-231 cells.

The results of estrogenic activity, detected by E-screen and expressed as $\mathrm{EC}_{50}$, showed a high potential of imatinib $\left(10^{-7} \mu \mathrm{M}\right)$ followed by cisplatin and 5-fluorouracil. Capecitabine was poorly estrogenic while etoposide and doxorubicin $\mathrm{EC}_{50}$ values were not possible to determine. Cytotoxicity was found at concentrations far from those detected in effluents. The potential endocrine activity of the most active drugs could be associated with human and wildlife risk when considering their occurrence in the environment.
\end{abstract}

(C) 2014 Elsevier B.V. All rights reserved.

\section{Introduction}

Cancer incidence is increasing in developed and, particularly, in developing countries not only because of the progressive increase of population aging but also because of risk factors such as tobacco and alcohol consumption, nutritional habits and environmental pollution.

Due to the worrying increase of cancer rates, the use of chemotherapy treatments is also rising with a related growing concern over the presence of cytostatics in water systems putting humans and aquatic organisms at risk (Johnson et al., 2008; Rowney et al., 2009). Although most anticancer drugs are administered in clinics or in hospitals with also healthcare worker occupational exposure concern (Castiglia et al., 2008; Pieri et al., 2010), from few years, home and day-hospital therapies are increasing, causing a continuous release of these chemicals directly into the municipal wastewater-treatment plants, usually not designed to treat such pollutants (Kosjek and Heath, 2011).

\footnotetext{
* Corresponding author. Tel.: + 390823274565.

E-mail address: marina.isidori@unina2.it (M. Isidori).
}

In light of the above-mentioned, the detection of cytostatics in wastewaters is rapidly growing and the concentrations found are worldwide from sub-ng to $\mu \mathrm{g} / \mathrm{L}$ as reported in Table 1 . Although these drugs are generally present in the environment at concentrations lower than those of other pharmaceutical classes (Kosjek and Heath, 2011), each living organism, humans included, may potentially be affected by their peculiar molecular mode of action. Recent studies showed sub-lethal and sub-organismal level effects of cytostatics on non-target organisms because of their mutagenic, genotoxic and teratogenic properties (Zounková et al., 2007, 2010) and, as all drugs in the environment, these chemicals might have chronic toxic effects on whole aquatic organisms acting as pseudo-persistent pollutants due to their continuous introduction into the environment (Fent et al., 2006a; Constantine and Huggett, 2010). Another effect of drugs, in any case detectable at very low concentrations, is the endocrine disruptor activity that has been drawing the attention of researchers in the last years. In fact, some xenoestrogens have the capability to mimic the female steroid hormone, $17 \beta$-Estradiol $\left(E_{2}\right)$. Different compounds act as Endocrine Disrupting Chemicals (EDCs) and their effects on the aquatic environment are known (Sumpter, 2005). In 
Table 1

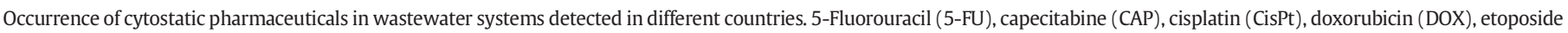
(ET) and imatinib (IM).

\begin{tabular}{|c|c|c|c|c|}
\hline Cytostatic & Matrix & Concentration detected & Countries & Ref. \\
\hline \multirow[t]{5}{*}{$5-\mathrm{FU}$} & Hospital effluent & $<5.0-27$ ng/L & Switzerland & Kovalova et al. (2009) \\
\hline & Hospital effluent & $20-122 \mu \mathrm{g} / \mathrm{L}$ & Austria & Mahnik et al. (2004) \\
\hline & Hospital effluent & $<8.6-124 \mu \mathrm{g} / \mathrm{L}$ & Austria & Mahnik et al. (2007) \\
\hline & Hospital wastewater & $35-92 \mathrm{ng} / \mathrm{L}$ & Slovenia & Kosjek et al. (2013) \\
\hline & Municipal wastewater & $4.7-14 \mathrm{ng} / \mathrm{L}$ & Slovenia & Kosjek et al. (2013) \\
\hline CAP & Wastewater effluent & $8.2-27.0 \mathrm{ng} / \mathrm{L}$ & Spain & Negreira et al. (2013) \\
\hline \multirow[t]{2}{*}{ CisPt as Pt compound } & Hospital influent & $3-250 \mu \mathrm{g} / \mathrm{L}$ & Austria & Lenz et al. (2007) \\
\hline & Hospital effluent & $2-150 \mu \mathrm{g} / \mathrm{L}$ & Austria & Lenz et al. (2007) \\
\hline \multirow[t]{4}{*}{ DOX } & Hospital effluent & $0.1-0.5 \mu \mathrm{g} / \mathrm{L}$ & Austria & Mahnik et al. (2006) \\
\hline & Hospital effluent & $<10 \mathrm{ng} / \mathrm{L}$ & China & Yin et al. (2010) \\
\hline & Hospital effluent & $<0.26-1.35 \mu \mathrm{g} / \mathrm{L}$ & Austria & Mahnik et al. (2007) \\
\hline & Wastewater influent & $4.5 \mathrm{ng} / \mathrm{L}$ & Spain & Martin et al. (2011) \\
\hline \multirow[t]{4}{*}{ ET } & Hospital effluent & $6-380 \mathrm{ng} / \mathrm{L}$ & China & Yin et al., 2010 \\
\hline & Hospital effluent & $110-600 \mathrm{ng} / \mathrm{L}$ & France & Catastini et al. (2008) \\
\hline & Wastewater effluent & $3.4 \mathrm{ng} / \mathrm{L}$ & Spain & Martin et al. (2011) \\
\hline & Wastewater influent & $15 \mathrm{ng} / \mathrm{L}$ & Spain & Martin et al. (2011) \\
\hline IM & - & - & - & - \\
\hline
\end{tabular}

different studies (Fent et al., 2006b; Isidori et al., 2009), some anticancer drugs such as tamoxifen, a selective estrogen receptor modulator (SERM) used in many estrogen-dependent cancers with a high estrogenic activity, were tested. Although hormone therapies with SERMs or selective estrogen receptor down-regulators (SERDs) are used for breast cancer treatment, drugs such as anthracyclines, taxanes and antimetabolites are also often used for breast chemotherapy and dispensed in combination regimens to increase the single drug efficacy (De Angelis et al., 2013; Lukyanova et al., 2009). But, do these agents have any estrogenic activity? Nowadays very little information is available about the endocrine disruption activity of anticancer drugs and their potential consequences for wildlife and humans when these compounds enter the aquatic sewer network.

In light of the increasing environmental concentrations of cytostatics and in view of the possible exposure to aquatic organisms and humans, the aims of the present study were to assess the in vitro estrogenic activity and the cytotoxic activity of six cytostatics belonging to the five classes of the World Health Organization (WHO) Anatomical Therapeutic Classification (ATC) scheme. The anticancers studied were: the antimetabolites 5-fluorouracil (5-FU) and its pro-drug orally administered capecitabine (CAP), the anthracycline doxorubicin (DOX), etoposide (ET), a topoisomerase II inhibitor belonging to the class of mitotic inhibitors, cisplatin (CisPt), a platinum derivative DNA cross-link agent and imatinib mesylate (IM), a potent and selective tyrosine kinase inhibitor. The estrogenic activity was investigated by two in vitro assays: a recombinant yeast system (YES test) expressing the human estrogen receptor $\alpha$ and the E-screen which measures estrogen-dependent growth stimulation in the human breast cancer cell line, MCF-7, ER $\alpha$ and ER $\beta$ positive. The estrogen receptor antagonist ICI 182,780, also known as Fulvestrant, was used to confirm the ER-related activity. Although in vitro estrogenic tests cannot fully predict a hazard to humans and particularly to wildlife, they are able to give an overall view concerning the estrogen mimetic potential of test compounds (Vanparys et al., 2010). The cytotoxic activity was assessed by the MTT Cell Proliferation Assay on two human breast cancer cell lines: the estrogen-dependent MCF-7 and the estrogen-independent MDA-MB-231 (ER ${ }^{-}$) cells to measure the cell viability.

\section{Materials and methods}

\subsection{Chemicals}

5-FU (CAS: 51-21-8), CisPt (CAS: 15663-27-1), DOX (CAS: 2531640-9), 17ß-Estradiol (CAS: 50-28-2), ET (CAS: 33419-42-0), $7 \alpha, 17 \beta-$ [9-[(4,4,5,5,5-pentafluoropentyl)sulfinyl]nonyl]estra-1,3,5(10)triene-3,17-diol (ICI 182,780, CAS: 129453-61-8), 2-nitrophenyl-B-Dgalactopyranoside (ONPG, CAS: 369-07-3) and 3-(4,5-dimethylthiazol2-yl)-2,5diphenyl-tetrazolium bromide (MTT, CAS: 298-93-1) were purchased from Sigma-Aldrich (Milano, Italy). CAP (CAS: 154361-50-9) and IM (CAS: 220127-57-1) were obtained from Santa Cruz Biotechnology (Santa Cruz, CA, USA). Yeast Nitrogen Base was purchased by BD Difco $^{\mathrm{TM}}$ (Milan, Italy). Dulbecco's modified Eagle's medium phenol red-free (DMEM), HEPES and Roswell Park Memorial Institute medium (RPMI 1640) were supplied by Lonza BioWhittaker (Verviers, Belgium).

\subsection{Yeast estrogen screen (YES)}

The YES-assay was carried out on Saccharomyces cerevisiae-RMY326 which was kindly supplied by Prof. Picard, Geneva University, Switzerland. This strain expresses a human estrogen receptor (hER $\alpha$ ) and includes expression plasmids carrying the reporter gene lac-Z, encoding the $\beta$-galactosidase, used to measure the receptor activity (Routledge and Sumpter, 1996). The yeast cells were grown for $24 \mathrm{~h}$ at $26{ }^{\circ} \mathrm{C}$ with shaking in the Yeast Nitrogen Base minimal medium enriched with amino acids and glucose. An aliquot of the culture was diluted in the fresh minimal medium and grown in the presence of five serial dilutions of pharmaceuticals for 16-18 h until growth reached the exponential phase $\left(2 \times 10^{7}\right.$ cells $\left./ \mathrm{mL}\right)$. $\mathrm{E}_{2}$ was assayed as the positive control from $10^{-5}$ to $10^{-1} \mu \mathrm{M}$. Then, yeast cells were harvested by centrifugation at $4000 \mathrm{rpm}$ for $5 \mathrm{~min}$ and the pellet re-suspended in $1 \mathrm{~mL}$ of Z-buffer ( $30 \mathrm{mM} \mathrm{Na}_{2} \mathrm{HPO}_{4}, 20 \mathrm{mM} \mathrm{NaH}_{2} \mathrm{PO}_{4}, 5 \mathrm{mM} \mathrm{KCl}, 0.5 \mathrm{mM} \mathrm{MgSO}_{4}$ ) plus a $0.025 \% \beta$-mercaptoethanol and centrifuged again. The pellet was re-suspended in $150 \mu \mathrm{L} Z$-buffer. $\mathrm{CH}_{2} \mathrm{Cl}_{2}(50 \mu \mathrm{L}), 0.1 \%$ sodium dodecyl sulfate $(20 \mu \mathrm{L})$ and Z-buffer $(30 \mu \mathrm{L})$ were added to the cells; the mixture was incubated for $5 \mathrm{~min}$ at $26^{\circ} \mathrm{C}$. The $\beta$-galactosidase reaction was started by adding $700 \mu \mathrm{L}$ of ONPG ( $4 \mathrm{mg} / \mathrm{mL}$ in Z-buffer) and stopped by adding $500 \mu \mathrm{L}$ of $\mathrm{Na}_{2} \mathrm{CO}_{3} 1 \mathrm{M}$. The $\beta$-galactosidase activity was determined by adding the colorimetric substrate, 2 -nitrophenyl- $\beta$ galactoside. The absorbance of the sample was measured at $420 \mathrm{~nm}$ (Garabedian et al., 1999). The $\beta$-gal units (Miller units) were determined using the following formula: OD420 $\times 1000 / \mathrm{t} \times \mathrm{V} \times$ OD600; where $\mathrm{t}=$ elapsed incubation time $(\mathrm{min}) ; \mathrm{V}=$ culture volume $(\mathrm{mL})$; and $\mathrm{OD} 600=$ absorbance of culture at $600 \mathrm{~nm}$. All experiments, in two replicates, were repeated three times and the median effective concentration ( $\mathrm{EC}_{50}$ ) was calculated by a non-linear regression (curve fit) model by GraphPad Prism 5 analysis. The Relative Inductive Efficiency (RIE) was determined by dividing the maximal $\beta$-galactosidase activity induced by the sample and the maximal activity induced by $E_{2}$ and expressing this ratio in a percentage. 


\subsection{Human cell lines}

Breast cancer cell lines MCF-7 and MDA-MB-231 were kindly provided by Prof. Ciro Abbondanza, Second University of Naples, Italy. For routine maintenance, both cell lines were grown in $25-\mathrm{cm}^{2}$ flasks (Sarstedt, Verona, Italy) using RPMI 1640 supplemented with 10\% fetal bovine serum (FBS), 2\% HEPES, 2\% L-glutamine and 1\% penicillin/ streptomycin, at $37{ }^{\circ} \mathrm{C}$ in an atmosphere of $5 \% \mathrm{CO}_{2}$, with $95 \%$ relative humidity. Cells were allowed to grow to the $80-90 \%$ confluence and then detached about twice a week by trypsinization.

\subsection{Proliferation assay (E-screen)}

E-screen assay was performed to determine the $17 \beta$-Estradiol $\left(E_{2}\right)$ dependent proliferation of human breast cancer ER ${ }^{+}$MCF-7 cells. The assay was carried out according to Soto et al.'s (1995) method, with slight modifications. Cells, seeded into 96-well plates (Sarstedt) at a density of 10,000 cells/well in $100 \mu \mathrm{L}$ of DMEM supplemented with antibiotics and 5\% dextran-coated charcoal treated FBS medium, were allowed to attach for $24 \mathrm{~h}$. Then, the medium was aspirated and replaced by $200 \mu \mathrm{L}$ of test compound solutions diluted in fresh DMEM medium, only medium for negative control and $\mathrm{E}_{2}\left(10^{-11}-10^{-4} \mu \mathrm{M}\right)$ for positive control, in six replicates for both each compound concentration and controls. Cells were maintained at $37{ }^{\circ} \mathrm{C}$ in a humidified atmosphere with $5 \% \mathrm{CO}_{2}$. After $120 \mathrm{~h}$, when the exponential phase of proliferation was complete, cells were treated with $20 \mu \mathrm{L}$ of MTT and incubated for $4 \mathrm{~h}$ at $37^{\circ} \mathrm{C}$ to let a mitochondrial enzymatic reduction of tetrazolium salts in purple-colored formazan products. After that, the medium was gently removed and replaced by 2 -propanol $(200 \mu \mathrm{L}$ per well). The absorbance was measured at $590 \mathrm{~nm}$ (Spectrafluor, Tecan, Männedorf, Switzerland).

The evaluation of cell proliferation was carried out by determining the Normalized Proliferation (NP) (Park et al., 2008), the ratio between the absorbance of compound concentrations and the absorbance of the most active concentration of positive control $\left(10^{-4} \mu \mathrm{M}\right)$, subtracting from both values the absorbance values of negative control, as shown in the following equation:

$\mathrm{NP}=\left(\mathrm{Abs}_{\text {test }}-\mathrm{Abs}_{\mathrm{NC}}\right) /\left(\mathrm{Abs}_{\mathrm{PC}}-\mathrm{Abs}_{\mathrm{NC}}\right)$

in which $\mathrm{Abs}_{\text {test }}, \mathrm{Abs}_{\mathrm{NC}}$ and $\mathrm{Abs} \mathrm{PC}_{\mathrm{PC}}$ are the compound, negative control and positive control absorbances, respectively.

The estrogenic-like activity of each sample, as endpoint of the E-screen assay, was evaluated determining the Relative Proliferative Effect percentage (RPE\%) using NP percent values to compare the proliferation induced by the sample to the highest induced by $E_{2}$. Moreover, for each test compound, three independent experiments were performed, then the median effective concentration $\left(\mathrm{EC}_{50}\right)$, was calculated by a nonlinear regression (curve fit) model by GraphPad Prism 5 analysis.

To verify the ER dependence of cell proliferation, the most active concentrations of both $\mathrm{E}_{2}$ and drugs, were co-treated with $1 \mathrm{nM} \mathrm{ICI}$ 182,780 , a well-known pure estrogen receptor antagonist. The concentration of ICI 182,780 was established in preliminary tests and according to the concentration utilized by Zhao et al. (2008). Statistical significant differences between compounds with and without fulvestrant were calculated with Student's $t$-test.

\subsection{MTT-assay (cytotoxicity)}

In the present work, the cell growth inhibition was determined on both cell lines by MTT assay, following the procedure of Berridge and Tan (1993). The cells grown in RPMI were trypsinized and resuspended in fresh medium for the vital counting using trypan blue. MCF-7 and MDA-MB-231 cells were seeded into 96-well plates at a density of 10,000 and 5000 cells/well respectively for 24 h to allow them to attach. Then, the medium was aspirated and replaced by $200 \mu \mathrm{L}$ of test compound diluted in fresh DMEM supplemented with antibiotics and the 5\% dextran-coated charcoal treated FBS medium. Each of the five-eight concentrations was tested in four replicates. A negative control ( $200 \mu \mathrm{L}$ medium) was included in each plate. After $48 \mathrm{~h}$ and $72 \mathrm{~h}$ of incubation, the cell growth inhibition was measured adding $20 \mu \mathrm{L}$ of MTT in each well and, after $4 \mathrm{~h}$ of incubation, the spectrophotometrically quantification was evaluated at $590 \mathrm{~nm}$ (Zhang et al., 2008). Cell inhibitory rate was calculated as: 1 - (compound absorbance / control absorbance) $\times 100$.

Three independent assays for each chemical were performed and the $\mathrm{IC}_{50}$ value, the concentration of compound necessary to obtain $50 \%$ of vitality inhibition, was calculated by concentration/response regression by nonlinear regression (curve fit) model (GraphPad Prism 5 analysis).

\section{Results and discussion}

In this study, we tested the possible estrogenic potency and cytotoxicity of six anticancers chosen on the basis of their consumption (Besse et al., 2012; Zhang et al., 2013) and on literature data about their concentrations in wastewater systems in various countries (Table 1).

\subsection{Estrogenicity}

None of the drugs examined was able to induce the expression of $\beta$-galactosidase in the YES test. Pharmaceuticals showed a very low estrogenic activity up to the highest concentrations tested which were in $\mu \mathrm{M}$ : 0.7 for 5 -FU, 11 for CAP, 8.3 for CisPt, 1.1 for DOX, 1.6 for ET and 2 for IM. Their very low activity did not allow the determination of the respective median effective concentration $\left(\mathrm{EC}_{50}\right)$, that was for $\mathrm{E}_{2}$ equal to $2.8 \cdot 10^{-4}\left(7.1 \cdot 10^{-5}-1.1 \cdot 10^{-3}\right) \mu \mathrm{M}$. Since the concentrations tested were far from environmental concern, we decided not to test higher concentrations.

Different from the YES test, four of the six investigated antineoplastics were found positive to the E-screen. Results of the MCF-7 of increased cell proliferation are summarized in Table 2 and expressed as a concentration of anticancer causing the $50 \%$ of Relative Proliferative Effect (RPE). The $\mathrm{E}_{2} \mathrm{EC}_{50}$ was observed at $9.49 \cdot 10^{-8} \mu \mathrm{M}$.

IM was the most active compound, followed by CisPt and 5-FU with $\mathrm{EC}_{50}$ values found in the order of $10^{-7}, 10^{-6}$ and $10^{-5} \mu \mathrm{M}$, respectively. CAP showed a lower effect ( $\mathrm{EC}_{50}$ value $0.48 \mu \mathrm{M}$ ) while ET and DOX EC 50 values were not found at concentrations ranging from $1.8 \cdot 10^{-6}$ to $1.8 \cdot 10^{-2} \mu \mathrm{M}$, indicating a low affinity for ERs at the concentrations tested. The ER is not a specific target of DOX, so that in a recent study the anti-proliferative activity and affinity of DOX towards ER $\alpha$ were

\section{Table 2}

Estrogenic activity of positive control $17 \beta$-Estradiol $\left(E_{2}\right)$ and cytostatics on MCF-7 cells evaluated as median effective concentration $\left(\mathrm{EC}_{50}\right)$ of Relative Proliferative Effect (RPE). The results are expressed in $\mu \mathrm{M}$ and in $\mu \mathrm{g} / \mathrm{L}$. In brackets: confidence limits (95\% probability).

\begin{tabular}{lll}
\hline Compound & $\mathrm{EC}_{50}(\mu \mathrm{M})$ & $\mathrm{EC}_{50}(\mu \mathrm{g} / \mathrm{L})$ \\
\hline $\mathrm{E}_{2}$ & $9.49 \cdot 10^{-8}$ & $2.60 \cdot 10^{-5}$ \\
& $\left(3.53 \cdot 10^{-8}-2.53 \cdot 10^{-7}\right)$ & $\left(9.53 \cdot 10^{-6}-6.89 \cdot 10^{-5}\right)$ \\
5 -FU & $1.93 \cdot 10^{-5}$ & $2.50 \cdot 10^{-3}$ \\
& $\left(3.31 \cdot 10^{-6}-1.12 \cdot 10^{-4}\right)$ & $\left(4.30 \cdot 10^{-4}-1.46 \cdot 10^{-2}\right)$ \\
CAP & 0.48 & 172 \\
& $(0.15-1.54)$ & $(53-553)$ \\
CisPt & $4.57 \cdot 10^{-6}$ & $1.37 \cdot 10^{-3}$ \\
& $\left(1.89 \cdot 10^{-6}-1.10 \cdot 10^{-5}\right)$ & $\left(5.67 \cdot 10^{-4}-3.30 \cdot 10^{-3}\right)$ \\
DOX & - & - \\
ET & - & - \\
IM & $1.23 \cdot 10^{-7}$ & $6.10 \cdot 10^{-5}$ \\
& $\left(2.90 \cdot 10^{-8}-5.80 \cdot 10^{-7}\right)$ & $\left(1.48 \cdot 10^{-5}-2.86 \cdot 10^{-4}\right)$ \\
\hline
\end{tabular}

-: Not determinable. 
increased covalently linking it to $\mathrm{E}_{2}$ (Saha et al., 2012). The Relative Proliferative Effects (RPEs\%) that compare the maximal proliferation induced by compounds to that induced by $\mathrm{E}_{2}$ are shown in Fig. 1 by doseresponse curves. The IM proliferation curve was very close to that of the positive control $\left(\mathrm{E}_{2}\right)$ showing the highest RPE percentage (77\% at $\left.5.1 \cdot 10^{-5} \mu \mathrm{M}\right)$ compared to the maximal $\mathrm{E}_{2}$ response $(\mathrm{RPE}=100 \%)$. The highest proliferation induced by 5 -FU was $74 \%$ at $7.6 \cdot 10^{-3} \mu \mathrm{M}$, and although this drug showed a maximum proliferative effect higher than CisPt $\left(67 \%\right.$ at $\left.3.3 \cdot 10^{-4} \mu \mathrm{M}\right)$, the CisPt $\mathrm{EC}_{50}$ value was one order of magnitude lower than the 5 -FU EC 50 value. CAP showed the highest RPE (96\%) but at very high concentration $(348 \mu \mathrm{M})$.

Based on the positive results obtained in the E-screen, experiments were performed to determine if the proliferation stimulatory effect of the selected cytostatics could be reversed by the estrogen receptor antagonist ICI 182,780 (Fig. 2). This is able to bind ER $\alpha$ and ERß, to impair its dimerization and to accelerate its degradation. Consequently, ER-mediated transcription is completely reduced, leading to the suppression of estrogen-dependent gene expression (Nuttall et al., 2001; Robertson, 2001). The highest proliferative effect obtained by $E_{2}(100 \%)$ was drastically reduced when MCF-7 cells were co-treated with the concentration of $1 \mathrm{nM}$ of ICI 182,780 (RPE $=28 \%$ ). The co-treatment of the anticancers with ICI 182,780 determined a significant decrease in responses $(p<0.01$ and $p<0.001)$ for all cytostatics except CAP which, unexpectedly, showed a maximum proliferative response of $130 \%$ when co-treated with an estrogen antagonist.

Our findings highlighted a better sensitivity of E-screen which uses the proliferative effect due to estrogens on their target cells when compared to the YES test which is based on the induction of reporter genes under estrogen-responsive elements control. It has to be considered that the yeast strain RMY326, here utilized, is transfected with a human $\alpha$-estrogen receptor while the MCF-7 cells contain both $\mathrm{ER} \alpha$ and ERß, and being vertebrate cells, they modulate the hormone response with complex systems of co-activation and co-repression (Shanle and $\mathrm{Xu}, 2011$ ).

The estrogenic activity of xenobiotics is difficult to predict because of their different modes of action, since depending on responses of ligands, there are both nuclear (genomic) and/or extra-nuclear (non-genomic) pathways (Shanle and $\mathrm{Xu}, 2011$ ). The findings obtained in the E-screen allow us to presume that CAP probably exerts its estrogenic properties via non-genomic pathway since ICI did not reverse its estrogen-induced cell proliferation (Fig. 2). Indeed, CAP is able to modulate and inhibit the NF-kB pathway involved in ER downregulation (Guzeloglu-Kayisli et al., 2008; Manu et al., 2012). The hypothesis of a non-genomic pathway activity could be applied also to IM which is a further NF-kB inhibitor (Ciarcia et al., 2012) but it could also have a genomic pathway (ER binding) as shown by its co-treatment with the antiestrogen ICI 182,780. As the estrogenic activities of CisPt and 5-FU were reversed by their co-treatment with the antiestrogen, it could be hypothesized that a genomic pathway was involved in their endocrine effect.

Although estrogen mimetic in vitro assays are suited to give an overall knowledge of the estrogenic potency of xenobiotics, our results, using the E-screen, are rather reliable because of the biological equivalence between the E-screen and the in vivo rodent uterotrophic assay as stated by Soto et al. (1995) and Vanparys et al. (2010).

The knowledge of potential endocrine disruption of pharmaceuticals in the environment is increasing and the activity of several drugs have been studied (Isidori et al., 2009; Pratilas and Solit, 2010; Margiotta-Casaluci et al., 2013) but only very little information is available on the estrogenic activity of cytostatics. Fent et al. (2006b) were among the first to report the hormonal effects of pharmaceuticals analyzing their estrogenicity as single compounds or in mixtures using the YES assay. In their study, among the drugs investigated, cytostatics such as doxorubicin showed no endocrine activity according to the present study, while tamoxifen, according to Isidori et al. (2009), presented a high estrogenic potential. The little information about the endocrine disrupting effects of cytostatics on one hand highlights a potential risk on human health through water recycling. On the other hand it makes an environmental impact evaluation difficult. An interesting way to predict the environmental effects of estrogenic drugs may be to compare the endocrine activity of such compounds to the long term exposure effects on non-target aquatic organisms. Most of studies are focused on the estrogenic effects in fish as the vitellogenin concentration and intersexuality assessment (Sumpter, 2005) even if, homologies between estrogenic receptors of vertebrate and invertebrate are often unexpectedly high suggesting the possibility that compounds with estrogenic activity could interfere with the reproduction also in invertebrates and phytoplankton (Clubbs and Brooks, 2007; Pratilas and Solit, 2010). On the basis of these considerations, it could be possible to consider the chronic toxicity effects on different organisms of the aquatic chain, to identify a potential estrogenic activity on

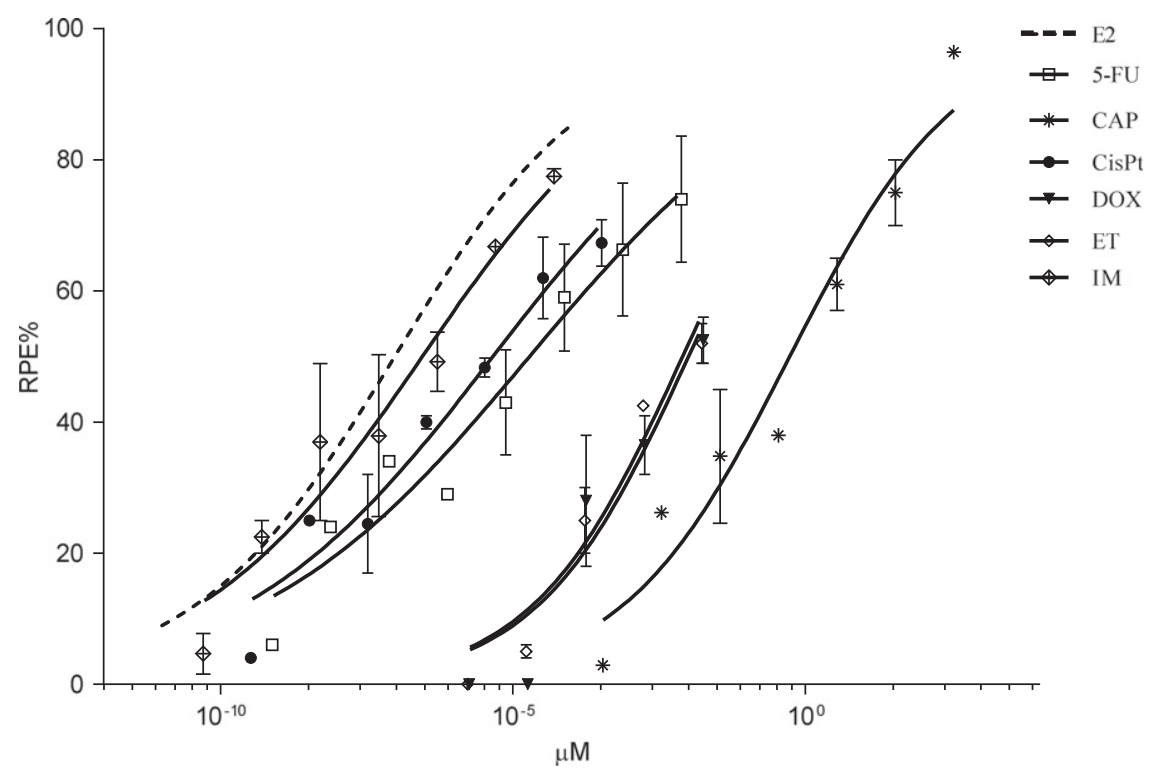

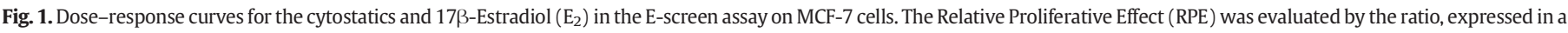

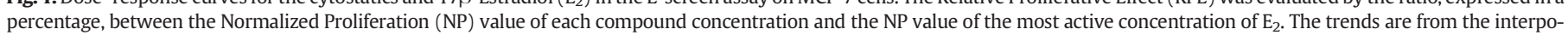
lation of three independent experiments, each one performed in six replicates, using GraphPad Prism 5. The results are expressed in $\mu \mathrm{M}$. Bars represent standard error. 


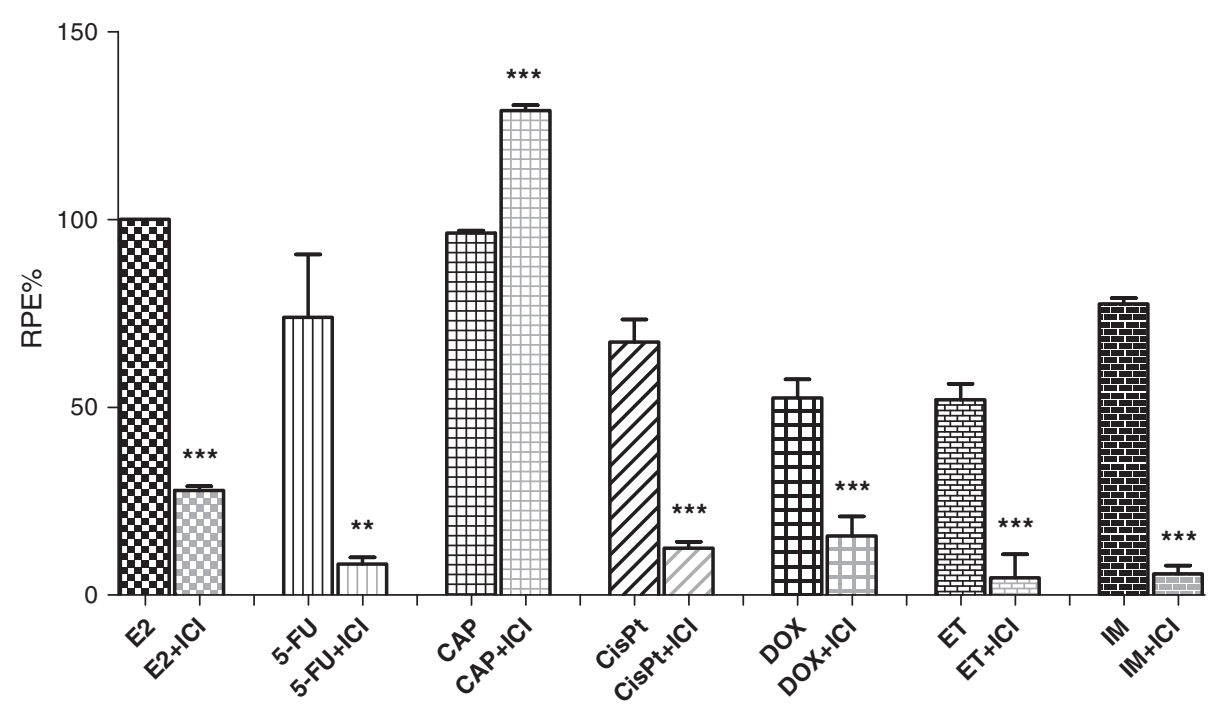

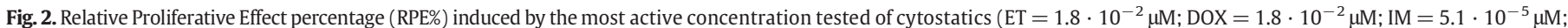

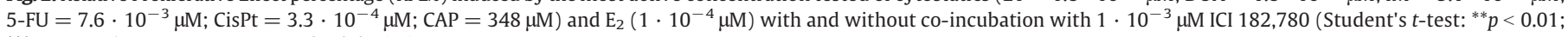
$\left.{ }^{* * *} p<0.001\right)$. Bars represent standard deviation.

such organisms. In a previous study, the chronic toxicity of six anticancer drugs was evaluated in crustaceans and CisPt and 5-FU, and to a lesser extent IM, showed the highest toxic potential inducing 50\% reproduction inhibition at concentrations in the order of $\mu \mathrm{g} / \mathrm{L}$ (Parrella et al., 2014). 5-FU was also found by Straub (2009) to affect the reproduction of Daphnia magna at concentrations below $10 \mu \mathrm{g} / \mathrm{L}$. Since in the present study the in vitro estrogenic activity was found at concentrations in the order of sub-ng/L for IM and ng/L for 5-FU and CisPt, it could be hypothesized that such activity could exert its effects on the reproductive process in a long term exposure. The increasing occurrence of cytostatic residues in hospital and municipal wastewater treatment plants raises concern for the aquatic systems where, despite the dilution of pollutant concentrations, a potential risk could be possible as these drugs act as pseudo-persistent pollutants because of their continuous introduction in the aquatic system.

Their concentrations vary under treatment practice, market basis and prevalence of cancers and the predicted environmental concentrations (PECs), despite their geographical specificity, could be useful to identify a potential risk. Besse et al. (2012), estimating the conservative predicted environmental concentration (assuming no human metabolism) of several anticancers in France, found IM, 5-FU and CisPt PECs in the order of $n g / L(19.95,39.57$ and 0.52 , respectively). IM and 5-FU PEC values were higher than the concentrations found to induce $50 \%$ of the estrogenic effect in the present study $\left(6.10 \cdot 10^{-2}\right.$ and $2.50 \mathrm{ng} / \mathrm{L}$ equivalent to $1.23 \cdot 10^{-7}$ and $\left.1.93 \cdot 10^{-5} \mu \mathrm{M}\right)$ while CisPt $\mathrm{PEC}$ was lower than its $\mathrm{EC}_{50}$. This comparison suggests that the potential endocrine activities of some drugs among those investigated, especially IM and 5-FU, might be associated to an ecological risk.

\subsection{Citotoxicity}

The cell growth inhibition, assessed on both estrogen-receptor positive (MCF-7) and estrogen-receptor negative (MDA-MB-231) human mammary carcinoma cells, was tested after 48 and $72 \mathrm{~h}$ of incubation. The level of cytotoxicity of the anticancers was assessed as a measure of the viability of the two cell lines at wastewater relevant concentrations and no cell viability inhibition was found at concentrations in the order of $n g-\mu \mathrm{g} / \mathrm{L}$. However, the $\mathrm{IC}_{50}$ values were estimated and the results are reported in Table 3 . At the control of cell viability (trypan blue) more than $95 \%$ of cells were viable. Generally, the two cell lines showed the same responses towards the tested compounds. The estimation of the $\mathrm{IC}_{50}$ values showed that DOX followed by ET,
CisPt and IM for both cell lines at 48 and $72 \mathrm{~h}$ of exposure was more cytotoxic than 5-FU and CAP. The cytotoxicity of DOX could be due to its mode of action because it is capable of breaking DNA strands and promoting DNA adducts blocking the replication of genetic material also at low concentrations (Quiles et al., 2002). Our results on DOX agree with those of Fawwaz et al. (2005) who found in their experiments an $\mathrm{IC}_{50}$ on MCF-7 of the same order of magnitude as that shown in Table 3. Furthermore, the weak cytotoxicity found for CAP was comparable to those found by Khvatova and Semeikin (2011) who used MCF-7 cells. The 5-FU cytotoxicity was higher in their study. Bielawski et al. (2010) found $\mathrm{IC}_{50}$ values for CisPt of $93 \pm 2$ and $82 \pm 2 \mu \mathrm{M}$ in MCF-7 and in MDA-MB-231 cells, respectively. These researchers used a $24 \mathrm{~h}$ incubation time that could explain the higher findings when compared to our results. Another supportive study tested the cytocidal activity of CisPt and several platinum complexes on the same breast cancer cell lines showing results comparable to ours (Descôteaux et al., 2008). In conclusion, we found cytotoxicity at concentrations in the order of $\mathrm{mg} / \mathrm{L}$, far from cytostatic mean concentrations detected in wastewaters (Table 1). Our results suggest that the in vitro cytotoxic activity of the anticancers studied is far from environmental concern even if an in vivo adverse effect could not be excluded in different taxonomic groups.

Table 3

Cytotoxicity expressed as median inhibitory concentration ( $\left.\mathrm{IC}_{50}\right)$ of the cytostatics on MCF-7 and MDA-MB-231 breast cancer cell lines after two incubation times (48 and $72 \mathrm{~h}$ ). The results are expressed in $\mu \mathrm{M}$. In brackets: confidence limits (95\% probability).

\begin{tabular}{|c|c|c|c|c|}
\hline \multirow[t]{3}{*}{ Compound } & \multicolumn{2}{|l|}{ MCF-7 } & \multicolumn{2}{|l|}{ MDA-MB-231 } \\
\hline & \multicolumn{4}{|l|}{$\mathrm{IC}_{50}(\mu \mathrm{M})$} \\
\hline & $48 \mathrm{~h}$ & $72 \mathrm{~h}$ & $48 \mathrm{~h}$ & $72 \mathrm{~h}$ \\
\hline 5-FU & $\begin{array}{l}738 \\
(424-1286)\end{array}$ & $\begin{array}{l}324 \\
(161-650)\end{array}$ & $\begin{array}{l}831 \\
(204-1387)\end{array}$ & $\begin{array}{l}73 \\
(31-175)\end{array}$ \\
\hline CAP & $\begin{array}{l}6550 \\
(4500-9510)\end{array}$ & $\begin{array}{l}2810 \\
(2170-3640)\end{array}$ & $\begin{array}{l}5130 \\
(4070-6460)\end{array}$ & $\begin{array}{l}2790 \\
(2140-3630)\end{array}$ \\
\hline CisPt & $\begin{array}{l}38 \\
(27-56)\end{array}$ & $\begin{array}{l}26 \\
(16-43)\end{array}$ & $\begin{array}{l}71 \\
(39-130)\end{array}$ & $\begin{array}{l}14 \\
(7-29)\end{array}$ \\
\hline DOX & $\begin{array}{l}15 \\
(12-18)\end{array}$ & $\begin{array}{l}9 \\
(5-18)\end{array}$ & $\begin{array}{l}19 \\
(8-46)\end{array}$ & $\begin{array}{l}4 \\
(1-16)\end{array}$ \\
\hline ET & $\begin{array}{l}87 \\
(14-394)\end{array}$ & $\begin{array}{l}21 \\
(4-93)\end{array}$ & $\begin{array}{l}17 \\
(6-51)\end{array}$ & $\begin{array}{l}2 \\
(0.4-16)\end{array}$ \\
\hline IM & $\begin{array}{l}62 \\
(52-73)\end{array}$ & $\begin{array}{l}57 \\
(42-78)\end{array}$ & $\begin{array}{l}59 \\
(38-96)\end{array}$ & $\begin{array}{l}31 \\
(21-46)\end{array}$ \\
\hline
\end{tabular}




\section{Conclusions}

Based on our findings, anticancers such as IM, CisPt and 5-FU may pose a risk for the environment and humans due to their estrogenic potency occurring at very low concentrations although no cytotoxic activity was found at environmental concentrations. It is clear that many additional studies should be carried out before arriving at a complete understanding of the environmental impact of such drugs because these compounds have different pharmacokinetics and pharmacodynamics that may induce unexpected effects. Furthermore, mixture studies should be considered to have a more realistic overview due to a continuous exposure to low levels of these pollutants since the risk for wildlife and humans is linked not only to the concentrations but also to the interactions that could induce additive, synergistic or antagonistic effects. However, this study will contribute to the knowledge of the overall toxicity of cytostatics.

\section{Conflict of interest}

The authors declare that there are not conflicts of interest.

\section{Acknowledgments}

This work was financially supported by the EU through the EU FP7 project CytoThreat (Fate and effects of cytostatic pharmaceuticals in the environment and the identification of biomarkers for an improved risk assessment on environmental exposure. Grant agreement no. 265264).

\section{References}

Berridge MV, Tan AS. Characterization of the cellular reduction of 3-(4,5-dimethylthiazol2-yl)-2,5-diphenyltetrazolium bromide (MTT): subcellular localization, substrate dependence, and involvement of mitochondrial electron transport in MTT reduction. Arch Biochem Biophys 1993;303:474-82.

Besse JP, Latour JF, Garric J. Anticancer drugs in surface waters: what can we say about the occurrence and environmental significance of cytotoxic, cytostatic and endocrine therapy drugs? Environ Int 2012;39:73-86.

Bielawski K, Bielawska A, Poplawska B, Surazynski A, Czarnomysy R. The effect of a nove dinuclear platinum complex with berenil and 2-picoline ligands on growth of human breast cancer cells. Acta Pol Pharm 2010;67:609-14.

Castiglia L, Miraglia N, Pieri M, Simonelli A, Basilicata P, Genovese G, et al. Evaluation of occupational exposure to antiblastic drugs in an Italian hospital oncological department. J Occup Health 2008;50:48-56.

Catastini C, Mullot J-U, Boukari S, Mazellier P, Levi Y, Cervantes P, et al. Assessment of antineoplastic drugs in effluents of two hospitals|. Eur I Wat Qual 2008;39:171-80.

Ciarcia R, Vitiello MT, Galdiero M, Pacilio C, Iovane V, D'Angelo D, et al. Imatinib treatment inhibit IL-6, IL-8, NF-KB and AP-1 production and modulate intracellular calcium in CML patients. J Cell Physiol 2012;227:2798-803.

Clubbs RL, Brooks. Daphnia magna responses to a vertebrate estrogen receptor agonist and antagonist: a multigenerational study. Ecotoxicol Environ Saf 2007;67:385-98.

Constantine LA, Huggett DB. A comparison of the chronic effects of human pharmaceuticals on two cladocerans, Daphnia magna and Ceriodaphnia dubia. Chemosphere 2010; 80:1069-74.

De Angelis C, Milano M, Stanzione B, Gargiulo P, De Placido S, Arpino G. Combination of cytotoxic drugs for patients with HER2-negative metastatic breast cancer. Comb Prod Ther 2013;3:25-37.

Descôteaux C, Leblanc V, Bélanger G, Parent S, Asselin E, Bérubé G. Improved synthesis of unique estradiol-linked platinum (II) complexes showing potent cytocidal activity and affinity for the estrogen receptor alpha and beta. Steroids 2008;73:1077-89.

Fawwaz SA, Iskandar ZA, Abdul-Rani S. The effects of chemotherapeutic drugs on viability, apoptosis, and surviving expression in MCF-7 cells. Acta Histochem Cytochem 2005; 38:323-30.

Fent K, Weston AA, Caminada D. Ecotoxicology of human pharmaceuticals. Aquat Toxicol 2006a;76:122-59.

Fent K, Escher C, Caminada D. Estrogenic activity of pharmaceuticals and pharmaceutical mixtures in a yeast reporter gene system. Reprod Toxicol 2006b;22:175-85.

Garabedian MJ, Iniguez-Lluhi JA, Kralli A. Yeast as a system for the study of nuclear receptor function. In: Picard D, editor. Nuclear receptors. New York: Oxford University Press; 1999. p. 233-59.

Guzeloglu-Kayisli O, Halis G, Taskiran S, Kayisli UA, Arici A. DNA-binding ability of NF- $\kappa B$ is affected differently by ER $\alpha$ and ER $\beta$ and its activation results in inhibition of estrogen responsiveness. Reprod Sci 2008;15:493-505.

Isidori M, Bellotta M, Cangiano M, Parrella A. Estrogenic activity of pharmaceuticals in the aquatic environment. Environ Int 2009;35:826-9.
Johnson AC, Jürgens MD, Williams RJ, Kümmerer K, Kortenkamp A, Sumpter JP. Do cytotoxic chemotherapy drugs discharged into rivers pose a risk to the environment and human environment. Trends Anal Chem 2008;30:1065-87.

Khvatova GI, Semeikin AV. Molecular-biological problems of drugs and mechanism of drug action. Comparative cytotoxicity of capecitabine and xeloda on cultured MCF7, HT-12, and rat thymocytes. Pharm Chem J 2011;44:651-3.

Kosjek T, Heath E. Occurrence, fate and determination of cytostatic pharmaceuticals in the environment. Trends Anal Chem 2011;30:1065-87.

Kosjek T, Perko S, Žigon D, Heath E. Fluorouracil in the environment: analysis, occurrence, degradation and transformation. J Chromatogr A 2013;1290:62-72.

Kovalova L, McArdell CS, Hollender J. Challenge of high polarity and low concentrations in analysis of cytostatics and metabolites in wastewater by hydrophilic interaction chromatography/tandem mass spectrometry. J Chromatogr 2009;A 1216:1100-8.

Lenz K, Koellensperger G, Hann S, Weissenbacher N, Mahnik SN, Fuerhacker M. Fate of cancerostatic platinum compounds in biological wastewater treatment of hospital effluents. Chemosphere 2007;69:1765-74.

Lukyanova NY, Rusetskya NV, Tregubova NA, Chekhun VF. Molecular profile and cell cycle in MCF-7 cells resistant to cisplatin and doxorubicin. Exp Oncol 2009;31:87-91.

Mahnik SN, Rizovski, Furhacker M, Mader RM. Determination of 5-fluorouracil in hospital effluents. Anal Bioanal Chem 2004;380:31-5.

Mahnik SN, Rizovski B, Fuerhacker M, Mader RM. Development of an analytical method for the determination of anthracyclines in hospital effluents. Chemosphere 2006; 65:1419-25.

Mahnik SN, Lenz K, Weissenbacher N, Mader RM, Fuerhacker M. Fate of 5-fluorouracil, doxorubicin, epirubicin, and daunorubicin in hospital wastewater and their elimination by activated sludge and treatment in a membrane-bio-reactor system. Chemosphere 2007;66:30-7.

Manu KA, Shanmugam MK, Ramachandran L, Li F, Fong CW, Kumar AP, et al. First evidence that $\gamma$-tocotrienol inhibits the growth of human gastric cancer and chemosensitizes it to capecitabine in a xenograft mouse model through the modulation of NF- $\mathrm{kB}$ pathway. Clin Cancer Res 2012. http://dx.doi.org/10.1158/1078-0432.

Margiotta-Casaluci L, Hannah RE, Sumpter JP. Mode of action of human pharmaceuticals in fish: the effects of the 5-alpha-reductase inhibitor, dutasteride, on reproduction as a case study. Aquat Toxicol 2013;128-129:113-23.

Martin J, Camacho-Munoz D, Santos JL, Aparicio I, Alonso E. Simultaneous determination of a selected group of cytostatic drugs in water using high-performance liquid chromatography-triple-quadrupole mass spectrometry. J Sep Sci 2011;34:3166-77.

Negreira N, López de Alda M, Barceló D. On-line solid phase extraction-liquid chromatography-tandem mass spectrometry for the determination of 17 cytostatics and metabolites in waste, surface and ground water samples. J Chromatogr A 2013; 1280:64-74.

Nuttall ME, Pendrak I, Emery JG, Nadeau DP, Fisher PW, Nicholson TA, et al. Antagonism of oestrogen action in human breast and endometrial cells in vitro: potential novel antitumour agents. Cancer Chemother Pharmacol 2001;47(5):437-43.

Park JY, Lee BC, Ra JS, Lee J, Kim SD. Effect of copper complexation on the estrogenic activities of endocrine-disrupting compounds using E-screen bioassay. Environ Toxicol Chem 2008;27:535-41.

Parrella A, Lavorgna M, Criscuolo E, Russo C, Fiumano V, Isidori M. Acute and chronic toxicity of six anticancer drugs on rotifers and crustaceans. Chemosphere 2014. http://dx.doi.org/10.1016/j.chemosphere.2014.01.013.

Pieri M, Castiglia L, Basilicata P, Sannolo N, Acampora A, Miraglia N. Biological monitoring of nurses exposed to doxorubicin and epirubicin by a validated liquid chromatography/fluorescence detection method. Ann Occup Hyg 2010;54:368-76.

Pratilas CA, Solit DB. Targeting the mitogen-activated protein kinase pathway: physiological feedback and drug response. Clin Cancer Res 2010;16:3329-34.

Quiles JL, Huertas JR, Battino M, Mataix J, Ramirez-Tortosa MC. Antioxidant nutrients and adriamycin toxicity. Toxicology 2002;180:79-95.

Robertson JFR. Faslodex (ICI 182, 780), a novel estrogen receptor downregulator-future possibilities in breast cancer. J Steroid Biochem 2001;79:209-12.

Routledge EJ, Sumpter JP. Estrogenic activity of surfactants and some of their degradation products assessed using a recombinant yeast screen. Environ Toxicol Chem 1996; 15(3):241-8

Rowney NC, Johnson AC, Williams RJ. Cytotoxic drugs in drinking water: a prediction and risk assessment exercise for the Thames catchment in the United Kingdom. Environ Toxicol Chem 2009;28(12):2733-43.

Saha P, Fortin S, Leblanc V, Parent S, Asselin É, Bérubé G. Design, synthesis, cytocidal activity and estrogen receptor $\alpha$ affinity of doxorubicin conjugates at $16 \alpha$-position of estrogen for site-specific treatment of estrogen receptor positive breast cancer. Steroids 2012;77:1113-22

Shanle EK, Xu W. Endocrine disrupting chemicals targeting estrogen receptor signalling: identification and mechanism of action. Chem Res Toxicol 2011;24:6-19.

Soto AM, Sonnenschein C, Chung KL, Fernandez MF, Olea N, Serrano FO. The E-screen assay as a tool to identify estrogens; an update on estrogenic environmental pollutants. Environ Health Perspect 1995;103:113-22.

Straub JO. Combined environmental risk assessment for 5-fluorouracil and capecitabine in Europe. Integr Environ Assess Manag 2009;6:540-66.

Sumpter JP. Endocrine disrupters in the aquatic environment: an overview. Acta Hydrochim Hydrobiol 2005;33:9-16.

Vanparys C, Depiereux S, Nadzialek S, Robbens J, Blust R, Kestemont P, et al. Performance of the flow cytometric E-screen assay in screening estrogenicity of pure compounds and environmental samples. Sci Total Environ 2010;408:4451-60.

Yin J, Shao B, Li K. A preliminary study on the occurrence of cytostatic drugs in hospital effluents in Beijing, China. Bull Environ Contam Toxicol 2010;84:39-45.

Zhang T, Zhang Q Chen D, Jiang J, Zhou Q. Growth inhibition of human breast cancer cell line MDAMB-231 by rosiglitazone through activation of PPAR $\gamma$. Chin J Clin Oncol 2008:5:407-12. 
Zhang J, Chang VWC, Giannis A, Wang JY. Removal of cytostatic drugs from aquatic environment: a review. Sci Total Environ 2013;445-446:281-98.

Zhao MR, Zhang Y, Liu WP, Xu C, Wang LM, Gan JY. Estrogenic activity of lambdacyhalothrin in the MCF-7 human breast carcinoma cell line. Environ Toxicol Chem 2008;27:1194-200
Zounková R, Odráška P, Doležalová L, Hilscherová K, Maršálek B, Bláha L. Ecotoxicity and genotoxicity assessment of cytostatic pharmaceuticals. Environ Toxicol Chem 2007; 26:2208-14.

Zounková R, Kovalova L, Dott W. Ecotoxicity and genotoxicity assessment of cytotoxic antineoplastic drugs and their metabolites. Chemosphere 2010;81:253-60. 